\title{
Diversity, Multiculturalism and Science Education at Enpec
}

\author{
Hiata Anderson Silva do Nascimento Brazil \\ Guaracira Gouvêa ${ }^{(1)}$ Brazil
}

The goal of this paper is to provide an overview of the thematic group created at the 2009 Enpec [Brazilian National Conference on Science Education Research] edition under the name Diversity, Multiculturalism and Science Education (DMSE). Our research question was: What is that working group like? We set out to examine the group's production considering the DMSE sessions to be a forum where research is presented and debated. The methodology involved reading and organizing presentation titles, abstracts, keywords, problem questions, and references using the Free Interpretation Analysis approach, which draws connections between a researcher's perspective and their study's theoretical framework. Graphs show the most frequent topics within DMSE studies and their oscillations over the years. This paper provides data and results indented to help: a) mapping Science Education studies, observing how they address the reality and the particular conditions of teaching-learning processes in different Brazilian schools; b) introducing a more critical vein to the education of those involved in Science Education, encouraging them to think beyond instrumental aspects and to incorporate a political and ethical approach committed to building a less unequal society and to the defense of human rights; and c) advocating for a more plural Science Education, in which diverse voices can be heard.

Keywords: Science Education; Diversity and Multiculturalism; Enpec.

\section{Introduction}

Since 1997, Enpec - Encontro Nacional de Pesquisas em Educação em Ciências [National Conference on Science Education Research] has become a capital forum for sharing information and research experience on Science Education in Brazil and even in Latin America. Enpec is a biennial event. Its contributions have become increasingly relevant to consolidate a knowledge area and also to configure an academic and scientific community whose work has proved crucial in the definition of public policy, aside from helping shape teachers' work in the classroom. An analysis of the meeting minutes available at Enpec's official website reveals that between 1997 and 2003 the event's format did not include thematic groups. This changed in 2005, when Enpec first began to be structured around thematic lines.

Over time, there where changes among and within the themes for each Enpec edition, as new thematic groups were created or certain topics were incorporated by different groups - as far as we can tell, all of these changes represented efforts to develop 
more favorable conditions for the discussions and exchanges between researchers working in similar areas.

The purpose of this paper is to provide an overview of the thematic group created at the 2009 Enpec edition under the name "Diversity, Multiculturalism and Science Education" (DMSE). Our research question is: What is that working group like? We set out to examine the DMSE production considering the group's sessions to be a forum where research is presented and debated as part of a major Science Education event; our strategy consisted of trying to discern the key aspects and trends within prevailing debates. The goal is to provide a broader look upon the DMSE thematic line, outlining its main vectors and inner workings so as to gain a better understanding of the nature of certain recent Science Education studies. We presuppose that much of the research currently connected to the DMSE thematic line was already under development before that line was created, and that the formal institution of the corresponding thematic group has resulted in public acknowledgment and granted institutional status to those investigations within Brazilian Science Education studies.

This study provides data that will contribute to: a) map Science Education studies, observing how they address the reality and the particular conditions of teaching-learning processes in different Brazilian schools; b) introduce a more critical vein to the education of Science Education teachers, encouraging them to think beyond instrumental aspects and to incorporate a political and ethical approach committed to building a less unequal society and to the defense of human rights; and c) advocate for a more plural Science Education, where diverse voices can be heard.

\section{Research methodology}

The first step was drawing a general picture of the research published at the Enpec meeting minutes. This was done by reading the titles of all papers presented between 1997 and 2019 (respectively, the first and last published event records). Our goal was to form a mental image of the event, trying to follow the changes on how the meeting minutes were organized for publication and on what sort of research was presented at Enpec. This stage took place between March and May of 2019 and comprised all oral presentations. The latest Enpec (2019) meeting minutes were analyzed in October of the same year, upon being made publicly available online by the event's Organizing Committee.

After reading the titles of all Enpec presentations, we narrowed the scope to the thematic group on diversity and multiculturalism since it seemed to concentrate an expressive amount of research integrating different knowledge areas and various theoretical and methodological approaches. There is a remarkable diversity among the theoretical approaches employed within a single thematic group, which points at new appropriations made by researchers committed to approaching their objects of study using the latest theoretical and methodological developments, especially the ones emerging from postgraduate Social Sciences and Humanities studies. After selecting a 
thematic area, we conducted a second reading of the DMSE meeting minutes, this time comprising paper titles, keywords and abstracts, with the goal of familiarizing ourselves with the discussions proposed by the group. In addition, we counted the keywords listed in all papers as a means of tracing a general outline of the group's activities. The following stage consisted of further reading, as we attempted to categorize the group's work based on the amount of papers related to the different foci comprised within the DMSE thematic line. After Delizoicov (2004), Jorge Megid and Cedoc/Unicamp have adopted thematic foci as the categorization criterion to chart Science Education research conducted in Brazil. We chose to employ the same concept in view of its solid suitability for the needs of this study.

We have also used the search function "Ctrl+F" to speed up the process of locating certain terms. It should be noted that the analysis and categorization was complicated by the fact that many papers could fit into two or more thematic foci. That likely stems from the very nature of the thematic session, since its title welcomes a wide array of studies structured around that nexus of organization and discourse. To address that difficulty, we enhanced our categorization grid to include the research questions and references of all papers, in addition to their titles, abstracts and keywords.

Reading the same body of texts repeatedly was an important methodological strategy towards the goal of identifying and extracting their general lines, internal orientations, key concepts, and composition structures. Such procedures are not far off from explication de texte, a scholarly exercise technique employed by masterful analysts such as Jacques Derrida (Williams, 2013).

Data structuring and interpretation were modeled using the Free Interpretation Analysis (FIA) approach, which endeavors connect the theoretical framework of a study to its author's teaching and researching perspectives and experiences (Anjos, Rôças, \& Pereira, 2019). Aside from illuminating the influence of the teaching and researching dimensions on how researchers signify their realities, FIA enabled us to realize how those very dimensions play a part in certain elements constitutive both of collective life in general and of human experiences in more specific contexts, such as the field of Science Education - conceived in a broader manner, as a knowledge production activity. Consequently, our research question and the subsequent investigation were formulated from a standpoint that assumes the likelihood of ties between authors' research and teaching experiences, the data and the theoretical frameworks of their respective studies. The interplay between those elements has proven rather promising to our reflections upon the papers presented on the DMSE thematic line at Enpec. 


\section{Thoughts on Enpec and the Diversity, Multiculturalism and Science Education thematic group}

In this section we reflect upon the meanings that circulate within a scientific event such as Enpec, focusing primarily on the symbolic aspects and power relationships that arise whenever a collectivity is constituted around a certain goal. Following that, we will present the data resultant from our analysis of the aforementioned meeting minutes and outline a profile of the DMSE thematic group, describing the key aspects and challenges that characterize this thought forum within the greater field of Science Education.

Over time, social and political matters have moved to the forefront of Enpec's activities. The 2019 edition - the first one to take place in Brazil's Northeastern region - happened in June 25-28 and featured a marked research interest on the interplay of social / cultural themes and Science Education. This may be regarded as a byproduct of the current political scene in Brazil, where many governmental choices and actions are widely considered regressive in terms of social and human rights. In that respect, Enpec subscribes to the theoretical standpoint from which scientific knowledge is considered a social and political endeavor committed to a set of values, thus breaking away from positivist views that advocate that knowledge can or should be neutral or nonhistorical. The analysis of the latest Enpec meeting minutes reveals that researchers are increasingly concerned with finding ways to incorporate into their work with Science Education matters related to the ongoing transformations in Brazilian society, especially political aspects and the dismantlement of democratic and popular public policy. The relevance of political engagement at the 2019 Enpec edition is easily discernible in the very title of its call for contributions: Difference, Social Justice and Democracy - four words of the greatest importance not just for the current academic scene, but also for Democratic Rule of Law and for the core meaning of our Constitution, signed in 1988. Practically all discussion forums featured defenses of public and secular education, centered on the concept of 'democratic school' and on its role for Science Education research.

As mentioned before, the event congregates diverse studies on a number of themes; nonetheless, we were able to identify a set of recurrent thematic foci at the DMSE session, whose number of papers and participants varies throughout different Enpec editions. Those thematic foci are: Science Education; Teacher Education; Inclusive Education; Education for Indigenous Peoples; Rural Education; Race Issues; Gender and Sexuality Issues.

Our analysis is centered on the oral presentations because those are instances of sharing and interaction among researchers who have in their thematic groups a rare opportunity to meet and to socialize their investigations and projects, as well as bolstering academic connections. In many ways, the thematic line meetings stage, materialize and render visible what is known as "thought communities". Such meetings constitute one of those moments when Science is represented, staged, performed and ritualized. According to the Durkheimian tradition, in those moments a collectivity is set in motion, as members break away from certain aspects of their everyday lives and 
also reinforce ties, values and feelings of collective belonging (Durkheim, 2014). Segalen (2002) writes that "There is no society that does not feel the need to regularly maintain and consolidate collective feelings. This moral reconstruction is accomplished through meetings and congregations" (p. 24.) In scientific events, there is more at play than a rational dimension (the suitability between means and ends, or the rational, technicallyoriented search for defined goals); those initiatives also involve moral and symbolic intents. Thus, whilst scientific events are indeed guided by a rational model there is much more to them, such as the symbolic and moral components of the meanings and intentions of social agents who participate in those gatherings.

Like all social life instances and every moment within a human community, such events have their own set of rituals. Enpec's rituals take place every other year and celebrate the role and the importance of research to build a meaning for Science, and to its very survival. In other words, Enpec and its thematic lines are situations in which the public and discursive dimension of Science is staged, presented and reinforced before the new members of that "thought community". Although the laboratory is considered a capital site for the performance of scientific knowledge, we cannot overlook the symbolic weight of scientific events as opportunities to materialize Science. In such events, the power and influence of researchers regarded as field references may be reasserted, but new scientists may also enter the scene and establish themselves as new references for their peers, thus ensuring the continuity of a certain hierarchical line of knowledge production, power and prestige. Therefore, Enpec editions form a series of moments linked in a logical sequence where, for a great many attendees, power is one of the goals. Enpec rituals help reinforce research practices and a certain manner of forming a Science Education researcher's identity, with all the challenges, the drama and joy involved in that process. The ties that make the community and collectivity sense noticeable are certainly strengthened during scientific events; however, we must not neglect the internal disputes for prestige and power (Bourdieu, 1998; Segalen, 2002).

As a historical and social dimension, Science is not without the ambiguities and dilemmas typical of the human condition. It is an activity ruled by highly rational procedures, in accordance with the Western view of rationality. As such, scientific actions must have well-defined goals and circumscribe the procedures by which those goals or aims are to be achieved. However, there is more to Science than rational actions: it can also be conceived as a mode of "rational action guided by values", where the value of "truth" or the search for a "truth" has a pivotal role in the set of practices adopted by scientists (Weber, 2000).

Consequently, even though in epistemological terms Science Education does not have the exact same parameters as scientific research, it still shares some of its founding or characteristic elements, as well as the institutional framework in which knowledge production follows Western guidelines. Therefore, by acting based on theoretical and methodological devices conceived within Social Sciences and Humanities, Science Education adheres to eurocentric epistemological approaches structured around a 
Western understanding of rationality, which underlies a significant portion of modern scientific-social thought. Social Sciences and Humanities are not exempt from modern ideals of scientificity. Those knowledge areas have played a major role in the Modern Era project of organization and control of human life, and this bleeds into all knowledge fields that draw theoretical and methodological support from them. Not until recently has this alliance come into question, both within Social Sciences and Humanities themselves and in Science Education, as researchers strive to conceive different ways of defining and producing knowledge (Castro-Gómez, 2000; Delizoicov, 2004; Grosfoguel, 2016; Oliveira, \& Queiroz, 2017; Outhwaite, 2017).

The institutions and values that guide collective life are only materialized when performed in human practices and actions. Their sole mode of existence is as actions and gestures repeated and staged by various social subjects throughout their lives, in a continuous process of mutual influences that repeats itself across history. It follows that we may posit that scientific events present many subjective and objective aspects of social phenomena, such as Bourdieu's habitus and field, as well as different sorts of capital - especially cultural and social capital, with participants competing amongst themselves to achieve prestige and social acknowledgment. Scientific events provide individuals with opportunities to present their capital portfolios as part of the struggle for acknowledgment and prestige intrinsic to the market, where knowledge producers and consumers are in attendance. Thus capital - especially cultural capital - is simultaneously a means and an end. As a means, it allows someone to gain access to the field and participate in exchanges with other competitors: capital is then the expression of a set of dispositions expressed in how one speaks and positions themselves before someone else, and it enables each participant to navigate the sites where Science is materialized. But capital is also an end, insofar as it is a goal, a target, an objective to be achieved by each and every scientific event attendee. The scientific field is structured around an institutional pleiad and as such it is a highly competitive arena with rules of its own, fueled by the tension between permanence and change, between established actors and newcomers (Bonnewitz, 2003; Bourdieu, 2009; Ortiz, 1983; Pinto, 2000).

The organization and layout of Enpec's website have changed significantly throughout the years, simplifying the access and search functions available to Science Education readers and researchers. The changes in its organization have made the website more attractive and accessible to internet users, which is easily spotted by comparing the meeting minutes of the 1997 and 2019 Enpec editions. Enpec grew larger, more complex, and richer in thematic, theoretical, and methodological diversity. Figure 1 shows the number of presentations in each DMSE session (the inaugural one took place at the 2009 Enpec edition). Data were extracted directly from the event's website and organized by the authors.

Despite an initial oscillation between 2009 and 2013, from 2015 onwards the number of presentations grew steadily. This is probably related to the expansion of Enpec itself, to the institutionalization of the thematic line and to how it became better 
known and more expressive within Science Education studies. If we look at the contents of the bulk of those presentations, another factor that may help explain this expansion are the transformations in the Brazilian social context, which posed new questions and dilemmas to scientific research. Between the years of 1997 and 2016 Brazil became a more democratic place, as a result of the actions and struggles of various social movements that drove the State to include in its educational and legal agenda a series of historical issues hitherto neglected, or poorly addressed at best. One example is law 10.639/2003, which regulates the inclusion of Afro-Brazilian History and Culture into the national syllabus. Another capital aspect of the broader national context are the work and actions of social movements linked to different groups, such as indigenous peoples, women, LGBTQI (Lesbians, Gays, Bisexuals, Transgender, Queer and Intersex people), people with disabilities etc., all of which are major social actors and have influenced educational public policy under governments more aligned with popular agendas. Therefore, the pressing issues and demands of a given historical moment do play a part in academic research and help shape the discussions taking place at scientific events. The increased research interest in DMSE has elevated it to the third place among all Enpec thematic lines: according to the event's website, in 2019 there were 131 DMSE presentations, the highest quantity after the two most reputable thematic lines in Science Education Teacher Education (264 abstracts) and Teaching and Learning Scientific Concepts and Processes (227 abstracts).

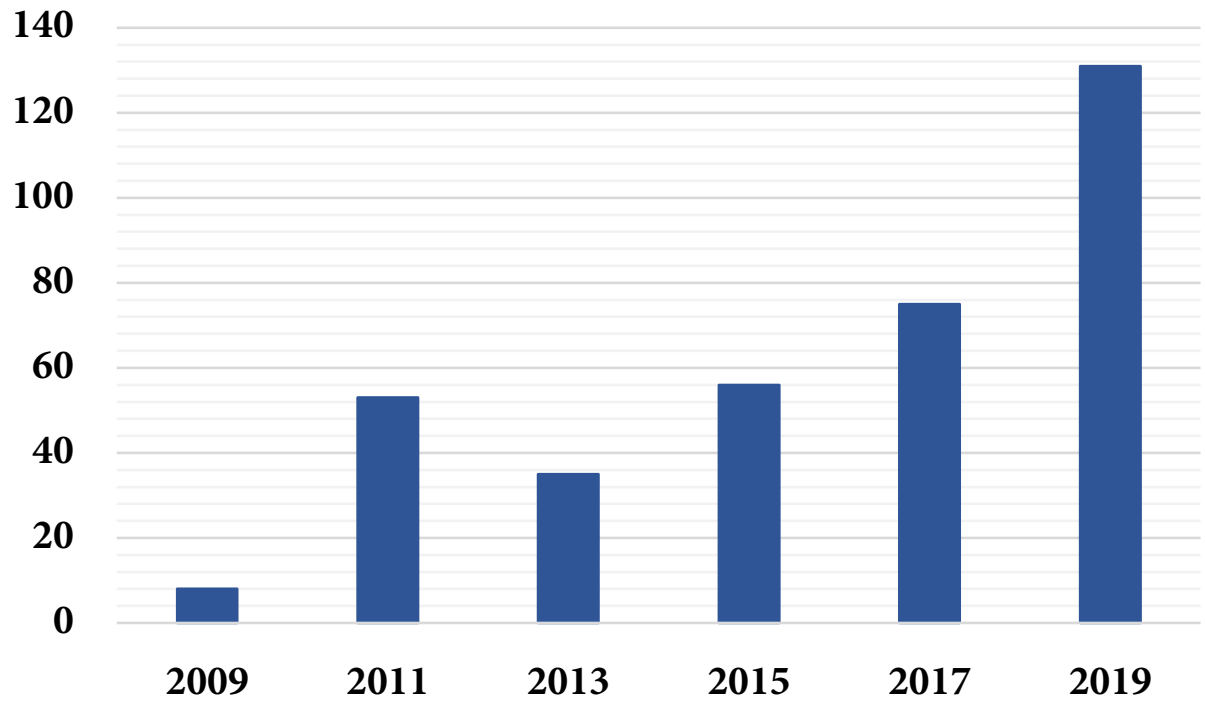

Figure 1. Number of presentations at the Diversity, Multiculturalism and Science Education thematic line over the years 
Any analysis of the keywords will depend on the selected organization criterion. Taken separately, the most frequent keywords are:

\begin{tabular}{|c|c|c|c|}
\hline Year & $1^{\text {st }}$ place & $2^{\text {nd }}$ place & $3^{\text {rd }}$ place \\
\hline 2009 & $\begin{array}{l}\text { Science education } \\
\text { ( } 3 \text { uses) }\end{array}$ & Teacher education (2 uses) & $\begin{array}{l}\text { Other keywords were used only } \\
\text { once. }\end{array}$ \\
\hline 2011 & $\begin{array}{l}\text { Science education } \\
\text { (9 uses) }\end{array}$ & $\begin{array}{l}\text { Chemistry Education; } \\
\text { Physics Education } \\
\text { (4 uses each) }\end{array}$ & $\begin{array}{l}\text { Science Education; teacher } \\
\text { education; cultural media } \\
\text { pedagogy ( } 3 \text { uses each). }\end{array}$ \\
\hline 2013 & $\begin{array}{l}\text { Science education } \\
\text { (13 uses) }\end{array}$ & $\begin{array}{l}\text { Cultural diversity; science } \\
\text { education; teacher education } \\
\text { ( } 5 \text { uses each) }\end{array}$ & $\begin{array}{l}\text { Gender; sexuality } \\
\text { (4 uses each) }\end{array}$ \\
\hline 2015 & $\begin{array}{l}\text { Science education } \\
\text { (20 uses) }\end{array}$ & $\begin{array}{l}\text { Teacher education; inclusion } \\
\text { ( } 5 \text { uses each) }\end{array}$ & $\begin{array}{l}\text { Science Education; deaf } \\
\text { education; science education; } \\
\text { gender; inclusion in schools } \\
\text { (4 uses each) }\end{array}$ \\
\hline 2017 & $\begin{array}{l}\text { Science education } \\
\text { (19 uses) }\end{array}$ & Rural Education (13 uses) & $\begin{array}{l}\text { Teacher education; gender } \\
\text { (10 uses each) }\end{array}$ \\
\hline 2019 & $\begin{array}{l}\text { Science education } \\
\text { (29 uses) }\end{array}$ & Gender (14 uses) & Rural Education (7 uses) \\
\hline
\end{tabular}

Figure 2. Keywords at Enpec's Multiculturalism, Diversity and Science Education sessions over the years

Science education and Teacher education concentrate most of the research presented at Enpec. However, it should be noted that each of these thematic lines presents considerable internal variety of topics and perspectives, as their researchers address more than science teaching at conventional schools. Numerous Teacher education studies focus on working with specific groups, such as students with special needs this includes topics and methods on how to teach deaf and hard of hearing students, blind students, students on the autism spectrum etc. as well as how to prepare teachers to educate in intercultural contexts, like those including indigenous peoples. Likewise, Science education presentations end up addressing many different topics, since Enpec allows its participants the freedom to submit papers to the thematic line of their choice. A key topic of interest is the development of didactic strategies to promote classroom teaching-learning processes. Even when they examine particular issues related to rural education, race, gender etc. the main object of all Enpec presentations is either or both Science education and Teacher Education. Therefore, these thematic lines can be considered "umbrella themes" for the other thematic foci and for this reason we thought it best not to include them in the images created to depict the DMSE debates.

Science education has the highest use rate of all Enpec keywords, and that number grows even more expressive when we take into account related terms, such as scientific education, Chemistry Education, Biology Education and Physics Education. 
This expresses two factors: first, that authors try to observe the central subject of the event; secondly, a growing interest in producing research on theoretical, methodological and teaching praxis aspects that can encompass the diversity, connections and didactic challenges inherent to Science Education. On those grounds, we may claim that there is an academic community formed by researchers who have effectively adopted Science education, in its various dimensions, as an object of study and of ethical and political attention.

Still somewhat recent, interculturality and related topics have received increasing research interest over the past decade. Between 2009 and 2019 there was a marked increase (see Figure 3) of Enpec presentations featuring the keywords interculturality or multiculturalism.

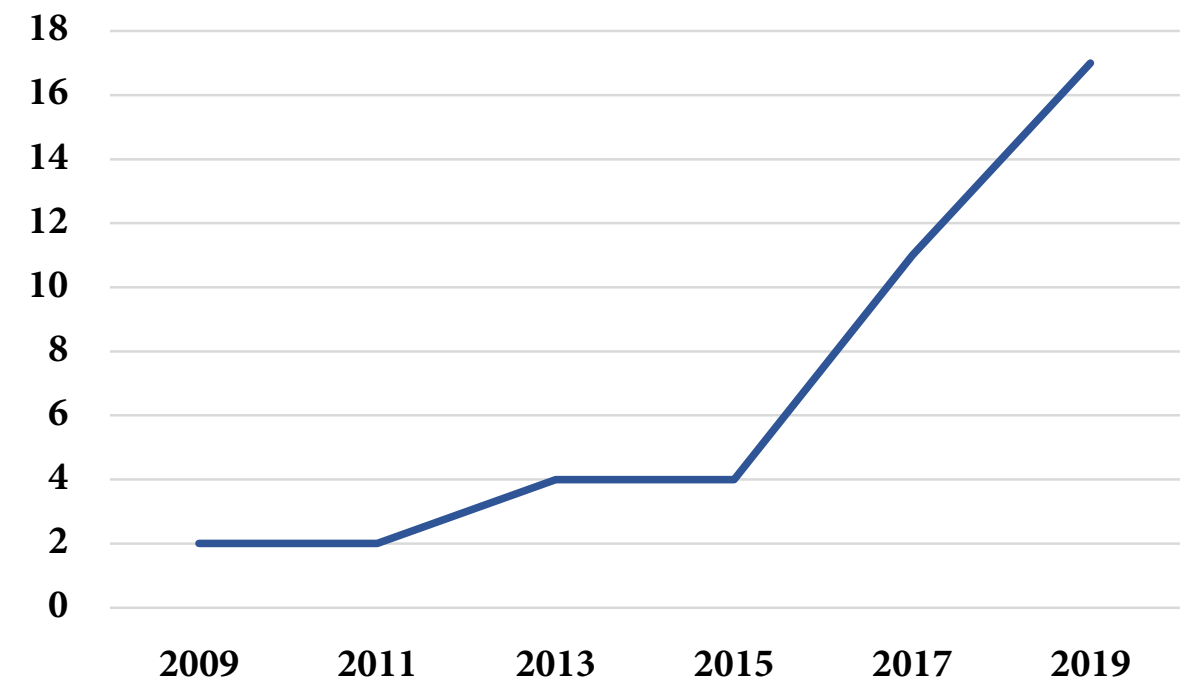

Figure 3. Use of Interculturality and related terms at Enpec over the years

The following terms were charted in Figure 3: multiculturalism, multiculturality, intercultural education, interculturality, critical multiculturalism, intercultural focus, intercultural scientific education, and Epistemologies of the South. This shows that over the years the topic has received increasing attention from Science Education researchers, to the point where it has become one of the leading topics in the field. This leaves us to wonder whether this debate will, at some point in the future, grow strong enough to produce changes within traditional Science Education syllabi and teaching practices, and whether it will ever be a key element of teacher education processes.

This study did not address the specificities of the different concepts of multiculturalism and interculturality used by Enpec researchers. Our goal was merely to understand how the topic as a whole has gradually been included on the ongoing Science education debates. Even so, one cannot overlook the fact that both terms refer to highly complex concepts with a veritable plethora of meanings, which play a strategic part on how we conceive the other and how that plays into our pedagogical praxis. Garcia, 2004 cited by Pizzinato (2013) explains that multiculturality admits diversity amongst cultures, 
acceptation of what is different and that it emphasizes difference, while interculturality is concerned with the confrontations and interrelationships that arise when different groups engage in exchanges, interactions and correspondence. This means that the focus is on the dialogue and negotiations between cultural communities. According to Pizzinato, Science Education research has yet to address these distinctions and both terms are used interchangeably. However, as Science Education researchers gradually appropriate these concepts - which in itself can be regarded as a positive development, especially due to how it helps put into question the many meanings of Science and its relationships with the concept of school and with other types of knowledge -, we can expect them to gain a progressively deeper understanding of this theoretical framework and start using it in a more critical manner, acknowledging its internal diversity and positioning themselves accordingly.

Figure 3 shows that the number of Enpec presentations addressing Interculturality has increased from 2017 onwards. On that same year the DMSE thematic group had a change of name to "Difference, Multiculturalism, Interculturality". The same thematic line received different names at the 2017 Enpec website and at the respective meeting minutes, probably due to a human mistake during the organization of the latter. On the main page of the 2017 Enpec website, it reads "Diversity, Multiculturalism, Interculturality and Science Education", while the sub-page listing the presentations reads "Diversity, Multiculturalism and Science Education", without the word "Interculturality". In 2019, both the committee list and the presentations index read "Difference, Multiculturalism, Interculturality". Therefore, we may see this change as a sign of the institutionalization of the thematic line at Enpec, and also as a call to researchers to consider the complexities and internal conceptual debates intrinsic to each of those terms - in order words, to regard them as theoretical-epistemological concepts that involve intense academic disputes over hegemony and meanings.

The term Multiculturalism encompasses a wide array of meanings. It falls within what is known as Post-critical Theories and can simultaneously function as a goal, a concept, a strategy, an attitude, and a value. It refers to the challenges faced by contemporary societies in view of the demographic changes and population displacements typical of our day and age, as well as their impact on the interactions between school and culture and on the problematization that requires from us. In Brazil, the multicultural debate raises dramatic issues such as exclusion, discrimination and the structural violence underlying our social and political foundations. Aside from a descriptive reading of our reality, multiculturalism poses the challenge of conceiving affirmative and interventionist measures to transform our bleak social life dynamics. For this reason, we need more than a liberal multiculturalism that advocates tolerance and respect for differences but fails to question the power structures conditioning social relations: we require a critical multiculturalism, such as the intercultural critical, poststructuralist or "more Marxist" variants (Moreira, \& Candau, 2013; Silva, 2013).

Another term that merits a closer look is "coloniality", from the decolonial 
theoretical framework. Quijano's (2005) seminal studies have paved the way for an evergrowing interest on the contributions of decolonial theories to socially-critical Science Education research. The first use of "Coloniality" was at the 2011 Enpec edition. At the time, the term seemed to be relatively unknown and was seldom used by researchers, even those working with an intercultural and decolonial framework. There are no records of prior studies using that theoretical perspective. Surprisingly, the 2011 presentation addressing coloniality was not allotted in the DMSE thematic session, but rather in the Science Teachers Education one. The presentation title is "Being vs. Knowing: symbolic effects of coloniality on the relationships between subjects and scientific knowledge", by Patrícia Barbosa Pereira and Suzani Cassiani. According to the authors, the study presents an "epistemological reflection about the conditions underpinning the actions of Brazilian teachers during the education of East Timor Science teachers" (p. 1). The study examines a cooperation program in which Brazilian teachers assisted in the education of their Timorese peers. The authors investigate how colonial power manifests in that sort of interaction, when one part assigns themselves the sole active role in teacher education processes. Pereira and Cassiani provide an overview of East Timor's social, cultural and political history and explain how the Brazilian cooperation efforts fit into that context. They warn about the risks of monologic contact in which one of the parts - in this case, the part sending the teaching mission tasked with educating Timorese teachers - presents and establishes themselves as the only ones entitled to a voice. Teacher education actions and initiatives must be regarded critically, and this applies to textbooks and other teaching resources as well as to the interactions between people and groups. Despite its own colonial history, in the exchanges with East Timor Brazil has acted as an intermediate between the colonizers and the Asian colony. The authors address the Science education actions that took place in that particular situation and argue for a Science that welcomes problematization and dialogic relationships with its context and reality, in direct contrast to cultural and epistemic homogenization processes (Pereira, \& Cassiani, 2011).

An initial assessment of the research presented at Enpec shows a rather limited number of studies with decolonial frameworks. Even amongst the studies that subscribe to intercultural theoretical perspectives, very few attempt to engage in critical intercultural and decolonial Science education research. There is still scant referencing of key decoloniality scholars, and the bulk of studies focuses basically on respecting differences and on the need to acknowledge the relevance of traditional knowledges, especially indigenous peoples'. Most presentations consist of experience reports that focus on pedagogical activities aimed at promoting interactions between scientific knowledge and the so-called popular knowledge - that knowledge which provides explanations for how the natural world works based on frameworks outside modern Western Science and which involve a different set of understanding categories, such as holism, subjectivity, religiousness, magical aspects etc.

Although decoloniality is still far from a widely spread framework, over the 
years there has been an increase in the number of studies emphasizing decolonial or critical intercultural approaches at Enpec, especially from 2013 onwards. The renowned decolonial pedagogy scholar Catherine Walsh is cited in four papers presented at the DMSE session. The first one is "O filme Jardim das Folhas Sagradas e a possibilidade de uma abordagem intercultural em aulas de Ciências" [The movie A Garden of Sacred Leaves and the possibility of adopting an intercultural approach in Science classes], presented by Oliveira, Trindade and Queiroz in 2013. The second one is "El enfoque intercultural en la enseñanza de las ciências" [The intercultural perspective in science education], presented by Pérez and Suárez in 2015. The remaining two were presented in 2019: "A distinção de saberes dentro dos processos de descolonização: campos temáticos baseados no mapeamento informacional bibliográfico" [The different knowledges within decolonization processes: thematic fields charted through bibliographic information mapping], by Mateus-Vargas, Anunciação and Andrade, and "Interculturalidade crítica, saberes populares e educação CTS em perspectiva freireana" [A freirean outlook on critical interculturality, popular knowledges and STS education], by Gondim and Gauche.

The first recorded citation of Aníbal Quijano's work at Enpec is in Mateus and Higuchi's (2015) study "Um mundo, olhares diferentes ou um olhar, mundos diferentes? Problematizando o perspectivismo ameríndio e questões ambientais" [A single world affording multiple perspectives or a single perspective for multiple worlds? A closer look at Amerindian perspectivism and environmental issues]. Quijano was also cited in two presentations at the 2019 Enpec edition: "A distinção de saberes dentro dos processos de descolonização: campos temáticos baseados no mapeamento informacional bibliográfico" [Distinctions among knowledges within decolonization processes: thematic fields charted through bibliographic information mapping], also by Mateus and Higuchi, and "A decolonialidade no Ensino de Ciências através da análise dos trabalhos publicados no Enpec" [Decoloniality in Science education: an analysis of Enpec presentations], by Castro and Monteiro.

Other studies on interculturality, decoloniality and Science Education were presented at Enpec since 2015, but they were allotted in different thematic sessions, such as the ones addressing Environmental Education and related topics. Contrary to our expectations, the studies on coloniality were also not allotted to the DMSE thematic line. Janning and Cassiani’s study "A Co-docência na formação de professores em Timor Leste: reflexões sobre colonialidade e transnacionalização" [Co-teaching and teacher education at East Timor: thoughts on coloniality and transnacionalization] (2015) was presented at Enpec session \#8- Languages, Discourse and Science Education.

Nonetheless, the 2019 Enpec edition definitely had the hitherto highest number of presentations featuring the keywords "decoloniality", "interculturality", and "intercultural". There were also studies with those keywords allotted to thematic lines other than Difference, Multiculturalism, Interculturality (the most recent name of the thematic line examined in this paper). Figure 4 depicts those trends: 


\begin{tabular}{|l|l|c|}
\hline Keyword & Thematic lines & Number of uses \\
\hline Decoloniality & Education in non-formal sites and scientific promotion & 1 \\
\hline \multirow{2}{*}{ Intercultural } & Teacher education & 2 \\
\cline { 2 - 3 } & Educational processes and resources & 1 \\
\hline \multirow{2}{*}{ Interculturality } & Teacher education & 1 \\
\cline { 2 - 3 } & Languages and Discourse & 1 \\
\hline
\end{tabular}

Figure 4. Uses of Decoloniality, Interculturality and Intercultural at other Enpec sessions

Another topic that has steadily risen to prominence at Enpec is Gender and Diversity. For quite some time, this topic was addressed mostly in Social Sciences and Psychology studies, but of late it has also received the attention of Science Education researchers. Based on the studies presented at the various Enpec editions, it is safe to say that there have been changes in how sexuality is discussed in Science classes, as teachers gradually abandon the prevalent biological, reproduction-centered approach that naturalizes heterosexuality and thus diminishes non-normative affective and sexual experiences. The studies presented at Enpec show that researchers are trying to think beyond the biological reproduction mechanisms and to regard human sexuality as a dimension of human life that is permeated by moral values, discursive debates and powerful instruments of social control over people's bodies. Given that families often face limitations and difficulties in discussing sexuality with young people, schools are a favorable site to form a sexual citizenship characterized by sexual ethics, respect for others and for people's freedom to be and to live however they choose to. For this reason, Egypto (2012) writes: "The school is a place where knowledge is being discussed, where dialogue and reflection are being engaged in. Therefore, it is a privileged site to discuss sexuality with children and teenagers." (p. 16). Under these conditions, by virtue of combining scientific information and an ethical stance that welcomes human singularities, Science education can play an important part in the formation of people's sexual citizenship, along with other knowledge fields. However, it is of the utmost importance to ask whether the studies presented at Enpec have any impact on classrooms or on teaching education, such as contributing to establish affirmative measures that can help dismantle prejudices and stereotypes commonly reproduced in schools.

Different Gender-related issues have been addressed at Enpec, such as the presence/absence of women in Science, gender disparity in the access to scientific education, homosexualities, sexual orientation, respect for differences, prejudice and discrimination, teenage pregnancy, analysis of didactic resources and how those can contribute to perpetuate of stereotypical mental images etc. Gender also comes up in studies focusing on Science teacher education initiatives. Figure 5 presents the changes in number of Enpec presentations discussing Gender. To filter out works that mentioned gender but did not have it as a central topic, we cross-related the keywords chosen by the author(s) of each study and thus the graph refers exclusively to presentations featuring gender-related keywords. 


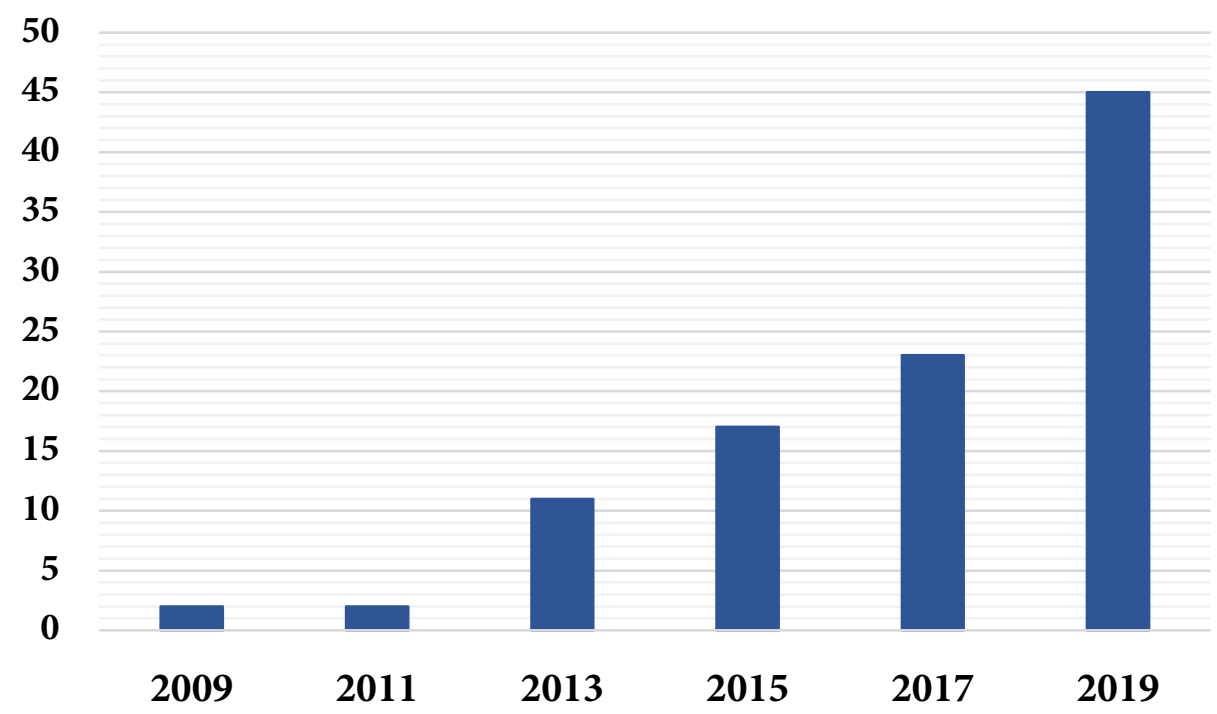

Figure 5. Evolution of descriptors related to Gender and Sexuality at the different Diversity and Multiculturalism Enpec sessions over the years

There is an increase on the frequency of gender-related keywords over the years. A 2009 scoping literature review to map the presence of Gender-related topics in Science education studies concluded that despite being a promising subject, Gender still received little research attention in the examined field (Júnior, Ostermann, \& Rezende, 2009). However, more recent data shows important changes: an increasing number of Science education researchers have incorporated Gender-related issues into their investigations, as shown in Figure 5.

An important contribution of Gender studies to Science Education is posing the issue of the existing disparity between girls' and boys' access to the fields of Physics, Chemistry and Mathematics, and how absolutely crucial it is to have teachers question this unequal configuration. Such questioning would involve deconstructing many of the gender norms and stereotypes that subconsciously guide certain conducts at schools, resulting in boys and girls having asymmetrical access to knowledge and sciencebased professions under the justification that boys would possess "natural" abilities predisposing them towards abstract knowledge and Mathematics, whereas girls would be more inclined to Humanities; this line of reasoning reinforces in many ways the different and unequal positions occupied by men and women both in public and in private spaces.

Consequently, Gender topics must be incorporated into teacher education processes as a key strategy for reflection and theoretical, ethical, and political combat, due to their usefulness in dismantling mental and cultural schemes still dominated by androcentric views of Science. Furthermore, it should be noted that some studies presented at Enpec stress that teachers feel unprepared to address homosexualities in the classroom, or have trouble doing it. The general picture consists of professionals reproducing in the classroom the - mostly unquestioning and often prejudiced - common 
sense views on the subject (Barreto, \& Araújo, 2009; Batista et al, 2015).

Although there are some citations of scholars such as Michel Foucault and Guacira Lopes Louro, Judith Butler is listed in the reference sessions of only four presentations throughout all DMSE sessions. That means that this key feminist thinker is explicitly listed as a reference only once in 2015 and three times in 2019. Considering Butler's currently central role in Gender studies, such meager referencing signals that Science education researchers could certainly use further reading of her studies and their many contributions to feminist thinking, to Science theories, political theories and definitely to the field discussed at Enpec. However, Enpec presentations do feature relatively more frequent mentions of Lopes Louro, one of the first scholars to introduce Butler's ideas in Brazil. For this reason, we believe that the Science education and Gender researchers who participated at Enpec did have, albeit indirectly, some contact with Butler's thoughts via professor Guacira Lopes' work.

In addition, given that nowadays the nature of Science and the scientific method are being called into question, Butler's analyses are a touchstone in the endeavor of questioning the naturalization of bodies, sexes and genders. Her work can provide important tools to analyze how gender rules are produced in and reproduced by the linguistic choices that take place in classrooms, in the interactions between students and teachers; they also help us question how natural beings are understood from a gendered standpoint (Franco, \& Munford, 2019). The very idea of nature, which is central in Natural Sciences, is dissected by Butler as something that presupposes the existence of entities outside the discursive arena - and thus exempt from social power relations. Therefore, her invigorating critique can help us acknowledge the power relationships underlying the foundation of Science, dislodge power instances and subvert dominant positions previously regarded as natural and therefore non-historical. Together with other scholars, Butler can contribute to the development of a more critical approach to one of the most important concepts within Natural Sciences: life. Beyond the more simplistic views that tend to describe life solely in biological terms, Butler's (2002, 2015) readings demonstrate that life is a category in dispute and that its varying definitions are influenced by different power relationships throughout history. In this context of conflicting meanings, the Natural Sciences are a pivotal discursive terrain in the battling definitions of the "truth" about living, as well as dying. Butler identifies life as something permeated by power mechanisms, and in so doing she enables us to cast a more critical look upon many key Natural Sciences issues. Although some studies presented at Enpec report that a number of Science teachers still claim to have trouble addressing Gender topics, Butler remains a crucial reference to be incorporated into Science teachers education processes, so as to prepare those teachers to think historically, politically and culturally about the knowledge they represent.

Quijano provides a deeper understanding of the various hierarchization modes in society and of how they are structured around a) the concept of race and b) a stratification between the knowledges produced by the various human communities. 
Thus, what Quijano does in effect is expose the direct impact of coloniality on modern scientific thinking, especially on Natural Sciences and their foundations, and how this has culminated in the erasure of divergent epistemologies and worldviews.

Eight papers were presented at the 2009 Diversity panel, two of which address gender issues and one addressing Education for Indigenous Peoples. The following charts present the changes in number of studies centered on each of the main topics encompassed by the DMSE thematic line, from 2009 onwards. Figure 6 depicts the changes in number of studies focusing on gender and diversity since 2011.

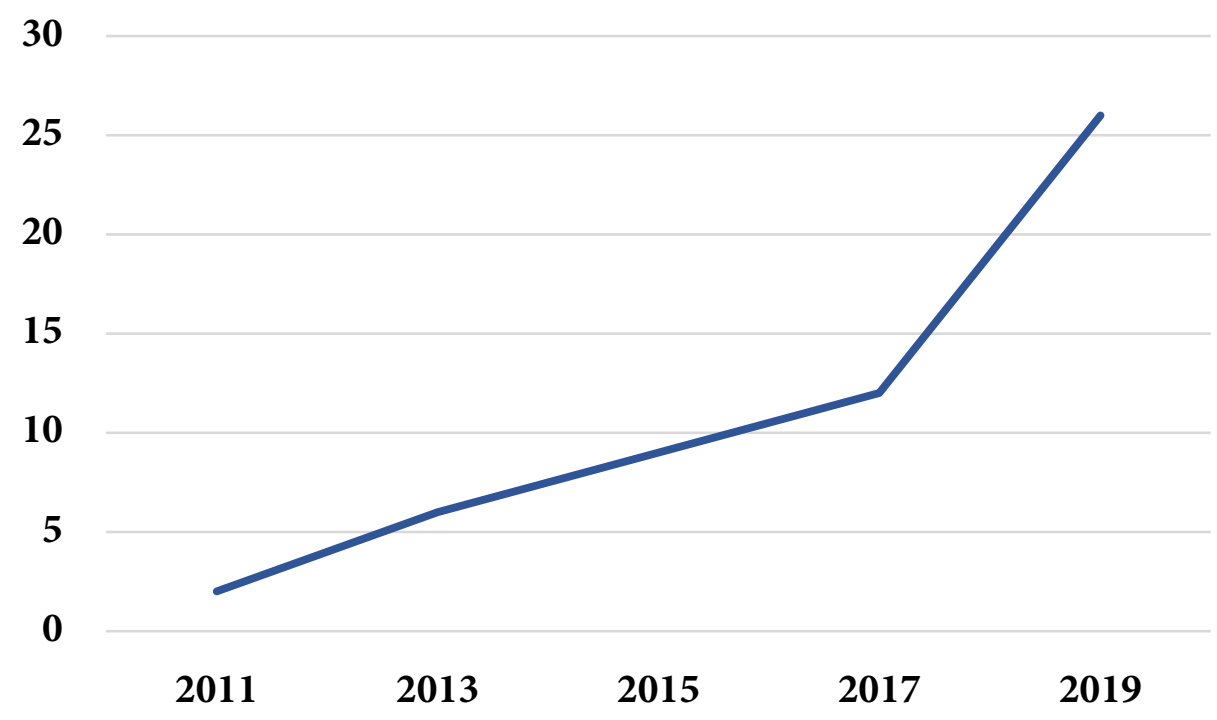

Figure 6. Changes in number of studies focusing on Gender and Diversity over the years

The changes in number of studies concentrating on race/ethnicity issues are shown in Figure 7.

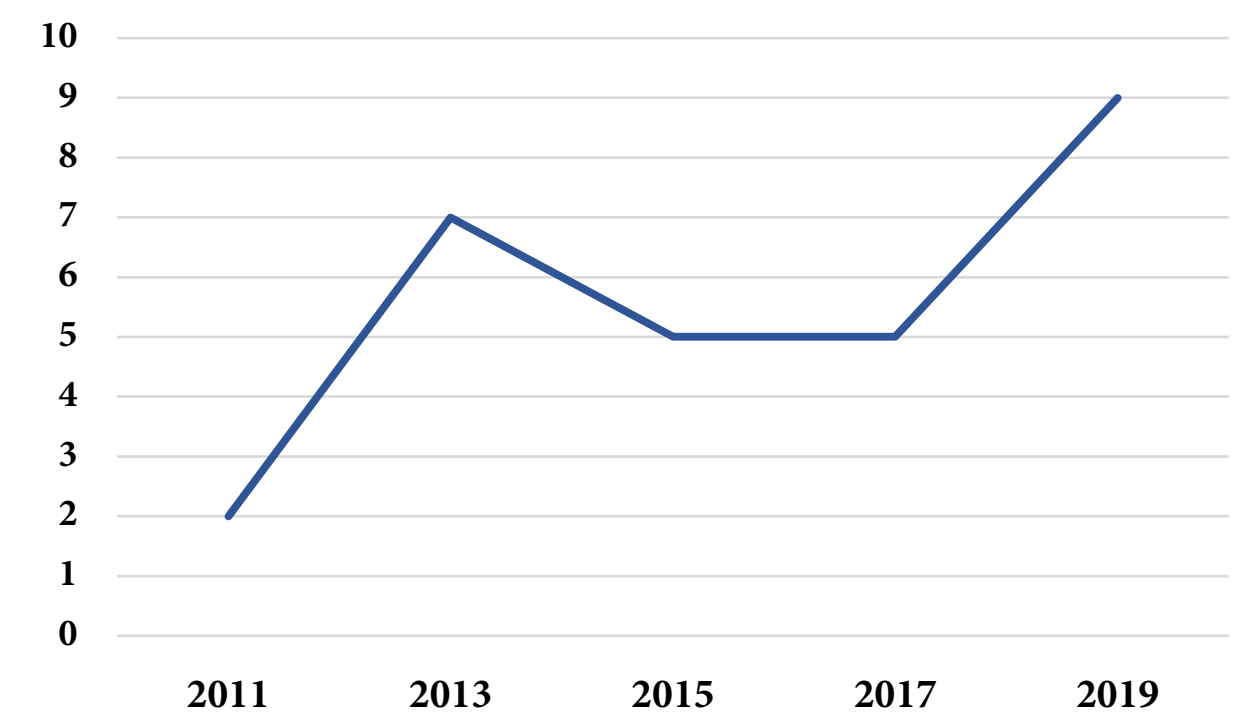

Figure 7. Changes in number of studies on Race over the years 
Most race-centered studies focus on the Brazilian law that tasks schools with addressing the subject, and the challenges posed by that directive to Science education. Moreover, researchers are concerned with racism at schools and trying to think of ways in which Chemistry, Biology and Physics can help fight that problem. There is a prevailing perception that these knowledges owe a historical debt over the epistemic silencing with which they have long met the great difficulties posed by racial issues. There is also concern over how those issues have gradually imbued the particular consolidation paths of Chemistry, Biology and Physics as school subjects, as well as the teacher education practices aimed at the professionals of those fields. Despite these developments and ethical commitments, we believe that the concept of race must be problematized even further as a political operator and subjected to deeper questioning. The majority of existing studies examines racial issues focusing on black populations, which can foster a worldview where racial issues concern exclusively those social groups. We need to question the meaning of whiteness, to regard it as a historical and social construction. In other words, researchers addressing race-related topics must work on the tools to dismantle the supposed naturality that grounds the white imaginary. If being a black man or a black woman is posited as something that merits reflection, the same must apply to being white, which is an identitary element conceived during the rise of coloniality/modernity and as such not exempt from power relations and historicity.

Figure 8 depicts the changes in number of studies focused on Rural Education.

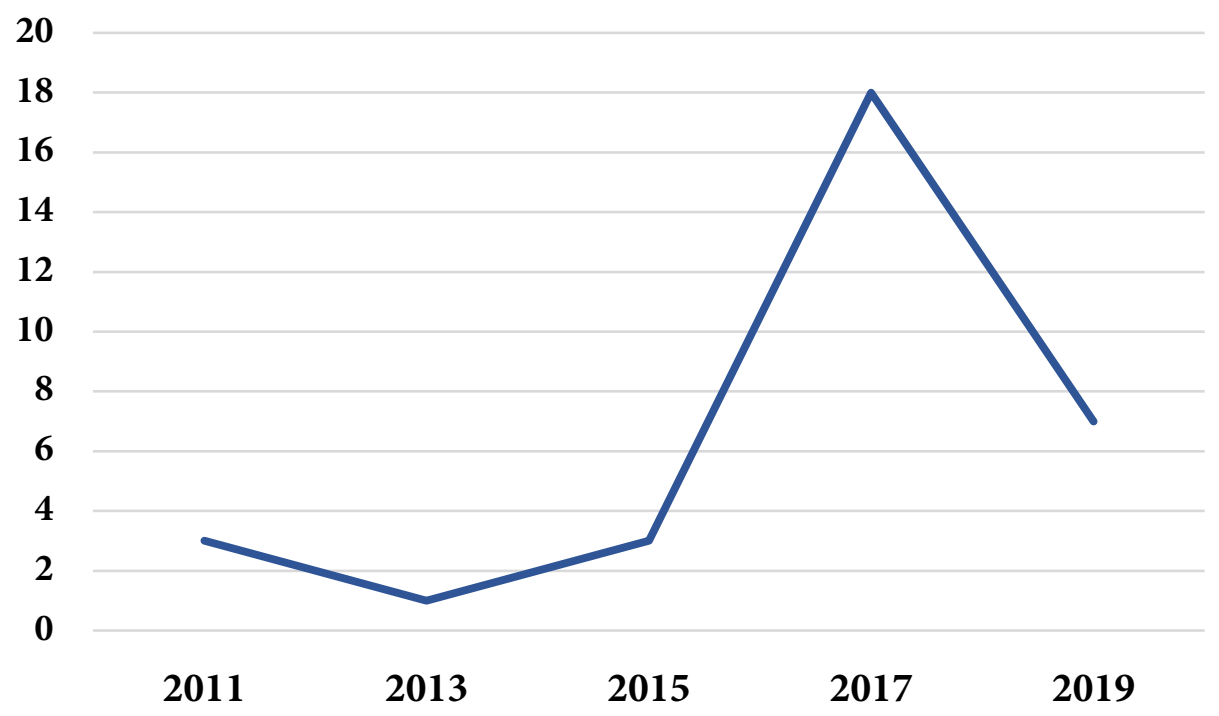

Figure 8. Changes in number of studies on Rural Education over the years 
Figure 9 shows the works focused on Education for Indigenous Peoples.

\section{6}

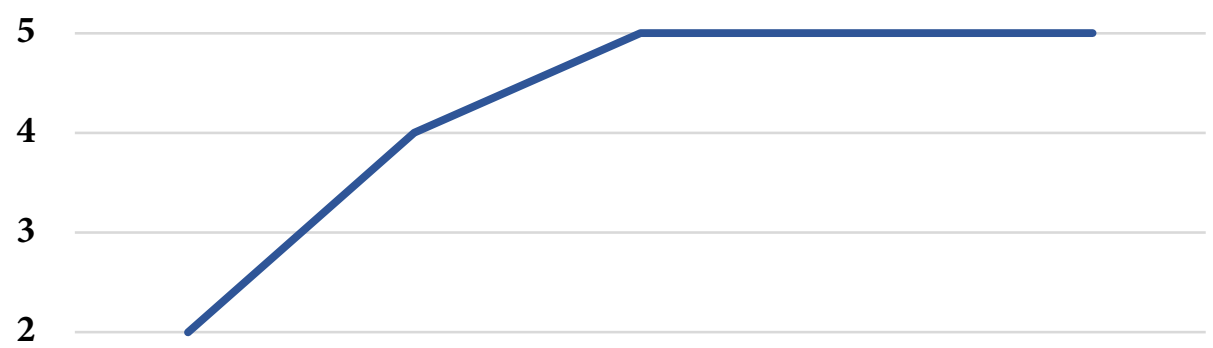

1

$\mathbf{0}$
2011
2013
2015
2017
2019

Figure 9. Changes in number of studies on Education for Indigenous Peoples over the years

Figure 10 depicts research on Inclusive education.

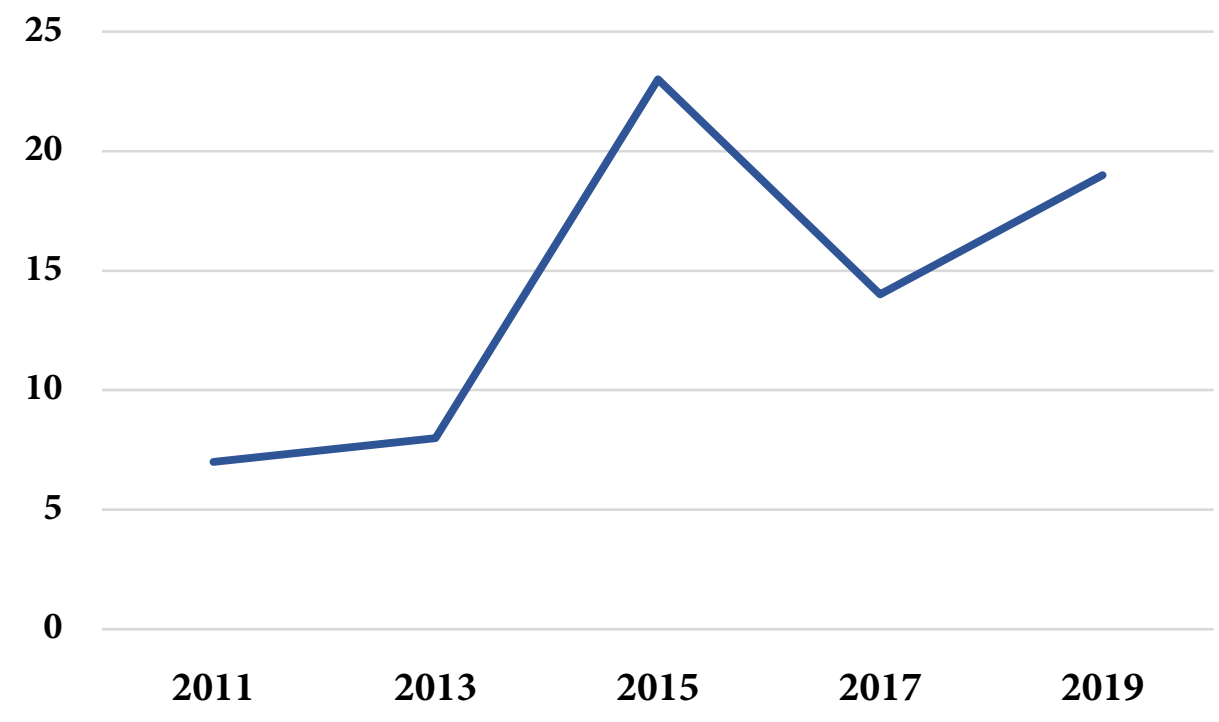

Figure 10. Changes in number of studies on Inclusive Education over the years

Notably, many studies address multiple topics at once. The most emblematic case is inclusive education, since a broader understanding of the term can potentially encompass gender issues and education for indigenous peoples as well as the pedagogic challenges of educating the deaf and hard of hearing, the blind and students with other disabilities. Faced with this categorization challenge, we have decided that the analysis would benefit from charting a more restrictive concept of Inclusive education (referring 
exclusively to people with disabilities), so as to avoid counting the same presentation multiple times.

As a whole, the presentations indicate a pressing need to consider the particularities of various groups within the Brazilian population, which points to the importance of valuing people's immediate contexts and their influence on teaching-learning processes. Therefore, the studies break away from "canned" pedagogical perspectives that, by failing to consider historical and social singularities and their implications to the learning process, tend to reinforce actions imbued with a more authoritarian worldview.

Regardless of the oscillations in number of studies focusing on the different topics welcomed at the DMSE Enpec sessions, there is a marked increase on the total number of presentations throughout the years. From the initial eight studies presented in 2009, the panel has reached the impressive mark of 131 presentations in 2019. Currently, the biggest challenge consists of thinking up ways to operationalize the studies' results and proposals in Brazilian and Latin-American classrooms. Any suggestions in that regard must take into account the recent changes in public policy and the reduction of public research financing, especially in the fields of Humanities and Education, whose legitimacy and relevance have been called into question by governmental actors. These governmental assaults are actually part of a larger social, political and economic context characterized by a progression of neoliberal reasoning that, besides economic austerity and a decrease of public investments, also operates by imposing a new subjectivation mold to be cultivated in education and which tends to turn that same education into merchandise, and schools into entities ruled by market-imposed metrics such as efficiency and competitiveness (Brown, 2018; Laval, 2019; Nussbaum, 2015).

This sort of debate prompts teacher education researchers to consider more than the instrumental dimensions of Science education, and thus the ethical aspect becomes a cornerstone of a pedagogical practice that acknowledges the contradictions of social life as well as the limitations of the hegemonic epistemology model and its view of Science; it calls for an ethical dimension that acknowledges the interplay between Science education and broader social issues, especially the political ones that interfere at schools. In face of all these challenges, it falls to each teacher to formulate, appropriate, and evaluate their own understanding of how those broad-range conditioning factors impact their work. From a critical standpoint focusing on the subalternization and dehumanization to which massive social groups are subjected, one may pose themselves the following questions:

(...) over time, have we agreed to work with our students following hegemonic norms or have we rejected those norms in favor of fostering critical, rebel, supportive, nonconformist, creative, autonomous identities? If we find that we have not been acting this way, how could we do it within our school subject? (Moreira, \& Candau, 2013, p. 51).

There is no escaping these questions. Even by responding to them with silence and indifference, teachers do indeed engage in a certain course of action and assume a stance towards the world and the reality of their students. A critical and self-questioning 
Science education - such as the one proposed by the studies presented at the DMSE thematic line - must take these questions on and incorporate perspectives that differ from the established thought and teaching traditions; teachers must put together, dismantle and then reassemble their own postulates, and act based upon mobility, openness and plurality, especially in these difficult times when our democracy is at risk. Post-Critical theories can contribute to broaden our range of action/reflection/action, in particular the following tenets of post-structuralism (a cornerstone of Butler's theoretical framework): a) questioning all discourse - this applies especially to the "truths" produced by Science as a privileged discursive field; b) not putting absolute faith in what is established; c) giving up homogeneous concepts in favor of exploring the various ways in which something can be thought of and understood; d) always prioritizing the denaturalization of life, suspecting what is held as normal/natural; e) not overlooking the role of power relationships in interactions and wondering about how they play into shaping subjects in certain ways etc. (Meyer, \& Paraíso, 2014).

Throughout the years, the studies presented at the DMSE Enpec sessions have underscored the need for broader understandings of both nature and Science. It might then be possible not just to ponder and rethink the limited representations of scientific practice that have the laboratory as its core locus, but also to incorporate into that scientific practices an array of social, cultural and political topics and issues, so as to effectively promote an intercultural and critical Science Education despite the current challenging scenario.

\section{Transitory conclusions and a few implications}

An overview of the studies presented at the various Enpec editions revealed a thriving research community committed not only to the consolidation of the field, but also to democratic and humane values. However, we have yet to find out to what extent those studies portray teachers' activities in the country's many schools and classrooms. Our analysis shows that questioning the meanings of Natural Sciences and breaking away from the more orthodox perspectives on scientific thought are major trends within the examined studies. The various research approaches share a common design of questioning the nature of scientific knowledge, but it is still unclear whether there have been any effective changes in the established pedagogical traditions in the field. In addition, when we look at the governmental changes in education during the last few years, it seems certain that we are at risk of a conservative turn towards a more technical education, with "no room" for political concerns or citizenship-building.

It is therefore our duty to come up with ways of resisting those processes. An event such as Enpec must take a stance and reinforce its purpose, which is not limited to sharing Science Education research but also involves bolstering democracy, human rights, freedom to teach and to learn, and defending the idea of Science as a universal cultural heritage whose work and results must be made accessible to everyone.

While Enpec as a whole has cultivated a considerable thematic diversity, the 
thematic line on Difference, Multiculturalism and Interculturality has come to be a key institutional instance to acknowledge the importance of plurality in Science Education. Data confirm that throughout the years the DMSE session became a beacon of academic thought and interaction. Let us not forget that in the 2019 Enpec edition that thematic line occupied the third place in number of presentations, after the two most reputable thematic lines in the field. The general picture emerging from the analysis offers a few contributions to Science Education: first, the scoping exercise mapped which issues mobilize research interest. That gives us a better understanding of the field and allows us to identify its strengths and weaknesses. These contributions are aligned to other studies that emphasize the capital importance of teacher education to improve Science Education. For this reason, it is crucial that more critical or post-critical theoretical approaches be incorporated to teacher education, so as to prepare teachers to think about race, gender, disabilities, rural education and education for indigenous peoples based on historical elements that can ground an ethical and political commitment to Brazilian citizenship and democracy.

The examined presentations show that there is ample room for improvement, especially in teacher education. How to connect Science teachers' education to the broader social and political changes? This is but one of the questions that emerge from our examination of the studies presented at the DMSE thematic line, when we think about the absolute impossibility of not being somehow affected by such changes. Aside from decidedly positive elements, such as the incorporation of new topics into Science Education studies, we are faced with the formidable challenge of having teacher education prepare professionals to position themselves not only about the technical and instrumental aspects of their respective specializations, but also to think critically about their own difficulties and prejudices when addressing questions that have long been rebutted by many field members on the grounds of being political, philosophical and sociological - and therefore irrelevant to Science Education pedagogical and research practices. In other terms, we must rethink the identity of Science teachers in a globalized and inter/multicultural world where authoritarian cultural versions still prevail - in Brazil, for instance. Such identitary rethinking cannot be achieved without revisiting and reviewing the history of Science Education and its academic disciplines, since the current identity is grounded on those histories. Just as academic disciplines are historical and social products, so are their identities which, rather than monolithic entities, are actually amalgams rife with conflicts and social struggles (Anjos, 2013; Viñao, 2008; Goodson, 2018). What does that say about the teaching identities whose foundations draw heavily from those disciplines? Thus, any changes upon teaching identities are bound to affect the internal composition of the respective academic disciplines and viceversa. Perhaps the inclusion of the broader topics addressed at various Enpec editions can effectively promote new practices and attitudes in classrooms?

That would certainly require further questioning and further struggles with the decisions and parameters expressed in the country's educational directives, aside 
from analyzing both the measurable and the possible impacts of the new theoretical frameworks on established Science Education teaching traditions. Whilst more critical perspectives, theories and procedures have been adopted by an expressive number of researchers, we have yet to verify how all of that has been operationalized in classrooms and whether there have been any changes in the hegemonic and long-established ways of conceiving and practicing Science Education.

It is always possible to intervene and to change social practices at any given moment. Therefore, if there is need to evaluate and transform, let us do that based upon solid and well-grounded knowledges and work towards responsible practices in line with better ethical stances.

\section{References}

Anjos,J.J.T. (2013). História das disciplinas escolares: Quatro abordagens historiográficas. Revista Reflexão e Ação. 21(n. esp), 281-298. http://dx.doi.org/10.17058/rea.v0i0.2590

Anjos, M. B., Rôças, G., Pereira, M. V. (2019). Análise de livre interpretação como uma possibilidade de caminho metodológico. Ensino, Saúde e Ambiente, 12(3), 27-39. https:// doi.org/10.22409/resa2019.v12i3

Barreto, M. I., \& Araújo, M. I. O. (2009). Professores e professoras de Ciências de Aracaju/ SE frente à homossexualidade. In VII Encontro Nacional de Pesquisa em Educação em Ciências. Florianópolis/SC.

Batista, I. L., Souza, D. C, Kikuchi, L. A., Corrêa, M. L., Heerdt, B., Stal, J. et al. (2015). Formação de professores no Brasil e questões de gênero feminino em atividades científicas. In X Encontro Nacional de Pesquisa em Educação em Ciências. Águas de Lindóia, SP.

Bonnewitz, P. (2003). Primeiras lições sobre a Sociologia de Pierre Bourdieu. Editora Vozes.

Bourdieu, P. (1998). O poder simbólico. Bertrand Brasil.

Bourdieu, P. (2009). A economia das trocas simbólicas. Editora Perspectiva.

Brown, W. (2018). Cidadania sacrificial: neoliberalismo, capital humano e políticas de austeridade. Zazie Edições.

Butler, J. (2002). Cuerpos que importam: sobre los limites materiales y discursivos del "sexo". Paidós.

Butler, J. (2015). Quadros de guerra: Quando a vida é passível de luto? Civilização Brasileira.

Castro, D. J. F. A., \& Monteiro, B. A. P. (2019). A decolonialidade no Ensino de Ciências através da análise dos trabalhos publicados no ENPEC. In XII Encontro Nacional de Pesquisa em Educação em Ciências. Natal, RN. 
Castro-Gómez, S. (2000). Ciencias sociales, violencia epistémica y el problema de la invención del otro. CLACSO/Consejo Latinoamericano de Ciencias Sociales.

Delizoicov, D. (2004). Pesquisa em Ensino de Ciências como Ciências Humanas Aplicadas. In R. Nardi (org). A pesquisa em Ensino de Ciências no Brasil: Alguns recortes (pp. 413-449). Escrituras Editora.

Durkheim, E. (2014). As formas elementares da vida religiosa: O sistema totêmico na Austrália. Martins Fontes.

Egypto, A. C. (2012). Orientação sexual na escola: Um projeto apaixonante. Editora Cortez.

Franco, L. G., \& Munford, D. (2019). O cotidiano da sala de aula e perspectiva de diálogo sobre gênero na pesquisa em Educação em Ciências. In XII Encontro Nacional de Pesquisa em Educação em Ciências. Natal, RN.

Gondim, M. S. C., \& Gauche, R. (2019). Interculturalidade Crítica, Saberes Populares e Educação CTS em perspectiva freireana. In XII Encontro Nacional de Pesquisa em Educação em Ciências. Natal, RN.

Goodson, I. F. (2018). Currículo: Teoria e história. Editora Vozes.

Grosfoguel, R. (2016). A estrutura do conhecimento nas universidades ocidentalizadas: racismo/sexismo epistêmico e os quatro genocídios/epistemicídios do longo século XVI. Sociedade e Estado, 31(1), 25-49. https://doi.org/10.1590/S0102-69922016000100003

Janning, D. P., \& Cassiani, S. (2015). A Co-docência na formação de professores em Timor Leste: Reflexões sobre colonialidade e transnacionalização. In X Encontro Nacional de Pesquisa em Educação em Ciências, Águas de Lindóia, SP.

Júnior, P. L, Ostermann, F., \& Rezende, F. (2009). Gênero e educação científica: uma revisão da literatura. In VII Encontro Nacional de Pesquisa em Educação em Ciências. Florianópolis, SC.

Laval, C. (2019). A escola não é uma empresa. Boitempo.

Mateus, W. D., \& Higuchi, M. I. G. (2015). Um mundo, olhares diferentes ou um olhar, mundos diferentes? Problematizando o perspectivismo ameríndio e questões ambientais. In X Encontro Nacional de Pesquisa em Educação em Ciências, Águas de Lindóia, SP.

Mateus-Vargas, M., Anunciação, B. C.P., \& Andrade, A. M. (2019). A distinção de saberes dentro dos processos de descolonização: campos temáticos baseados no Mapeamento Informacional Bibliográfico. In XII Encontro Nacional de Pesquisa em Educação em Ciências. Natal, RN.

Meyer, D. E., \& Paraíso, M. A. (2014). Metodologias de pesquisa pós-criticas em educação. Mazza Edições. 
Moreira, A. F., \& Candau, V. M. (2013). Multiculturalismo: Diferenças culturais e práticas pedagógicas. Editora Vozes.

Nussbaum, M. (2015). Sem fins lucrativos: Por que a democracia precisa das humanidades? Editora WMF Martins Fontes.

Oliveira, R. D. V. L., \& Queiroz, G. R. P. C. (2017). Conteúdos cordiais: Química humanizada para uma escola sem mordaça. Editora Livraria da Física.

Oliveira, R. D. V. L., Trindade, Y, R. A., \& Queiroz, G. R. P. C. (2013). O filme 'Jardim das folhas sagradas e a possibilidade de uma abordagem intercultural em aulas de ciências. In IX Encontro Nacional de Pesquisa em Educação em Ciências. Águas de Lindóia, SP.

Ortiz, R. (1983). Pierre Bourdieu: Sociologia (Coleção Grandes Cientistas Sociais). Editora Ática.

Outhwaite, W. (2017). Teoria social: Um guia para entender a sociedade contemporânea. Zahar.

Pereira, P. B., \& Cassiani, S. (2011). Ser X Saber: Efeitos simbólicos da colonialidade nas relações entre os sujeitos e o conhecimento científico. In VIII Encontro Nacional de Pesquisa em Educação em Ciências. Campinas, SP.

Pérez, M. U., \& Suárez, C. J. M. (2015). El enfoque intercultural en la enseñanza de las ciências. In IX Encontro Nacional de Pesquisa em Educação em Ciências. Águas de Lindóia, SP.

Pinto, L. (2000). Pierre Bourdieu e a teoria do mundo social. Editora FGV.

Pizzinato, L. A. R. (2013). Estudos sobre a diversidade cultural e ensino de ciências na Colômbia. In IX Encontro Nacional de Pesquisa em Educação em Ciências. Águas de Lindóia, SP.

Quijano, A. (2005). Colonialidade do poder, Eurocentrismo e América Latina. In Lander, E. (org). Colonialidade do saber: Eurocentrismo e ciências (pp. 345-392). Conselho Latino-Americano de Ciências Sociais.

Segalen, M. (2002). Ritos e rituais contemporâneos. Editora FGV.

Silva, T. T. (2013). Documentos de identidade: Uma introdução às teorias do currículo. Editora Autêntica.

Viñao, A. (2008). A história das disciplinas escolares. In Revista Brasileira de História da Educação, 8(3 [18]), 173-215.

Weber, M. (2000). Economia e sociedade (v. 1). Editora da UnB.

Williams, J. (2013). Pós-estruturalismo (2. ed.). Editora Vozes. 
Hiata Anderson Silva do Nascimento

[1] https://orcid.org/0000-0002-6751-8395

Universidade Federal do Rio de Janeiro

Núcleo de Tecnologias Educacionais para a Saúde Programa de Pós-Graduação em Educação em Ciências e Saúde

Rio de Janeiro, Rio de Janeiro, Brazil hiata.nascimento@ifes.edu.br

\section{Guaracira Gouvêa}

https://orcid.org/0000-0001-5955-6992 Universidade Federal do Estado do Rio de Janeiro Programa de Pós-Graduação em Educação Universidade Federal do Rio de Janeiro Núcleo de Tecnologias Educacionais para a Saúde Programa de Pós-Graduação em Educação em Ciências e Saúde Rio de Janeiro, Rio de Janeiro, Brazil

Submitted on 13th March 2020 Accepted on 09th June 2020 Published on 03rd July 2020 